\title{
ANALISIS PELAKSANAAN PERATURAN DAERAH NOMOR 9 TAHUN 2001 TENTANG PENERTIBAN TEMPAT HIBURAN DI KOTA PAREPARE
}

\author{
Analysis of The Implementation of Regional Regulation Number 9 of 2001 Concerning Control of \\ Entertainment Places in Parepare City
}

\author{
Asdinar Tawasty Nur Abbas ${ }^{1}$, Baso Madiong', Zulkifli Makkawaru ${ }^{2}$ \\ ${ }^{1}$ Magister Ilmu Hukum Program Pascasarjana, Universitas Bosowa \\ ${ }^{2}$ Program Studi Ilmu Hukum, Program Pascasarjana, Universitas Bosowa \\ Email: asdinardinar5@gmail.com \\ Diterima: 06 Januari 2021 \\ Dipublikasikan: 07 Juni 0221
}

\begin{abstract}
ABSTRAK
Penelitian ini bertujuan untuk mengetahui dan memahami upaya penegakan hukum dalam Pelaksanaan Peraturan Daerah Nomor 9 Tahun 2001 Tentang Penertiban Tempat Hiburan Di Kota Parepare serta Faktor-faktor yang mendukung dan menghambat dalam Pelaksanaan Tempat Hiburan Di Kota Parepare. Oleh karena itu penegakan hukum dan pengawasan usaha diperlukan untuk mengendalikan Penyelenggaraan usaha karaoke agar berjalan sesuai dengan aturan. Penelitian ini dilakukan di Kota Parepare dengan Objek penelitian adalah Badan Perizinan dan Satu Pintu Penanaman Modal Di Kota Parepare dan Dinas Kepemudaan, Olah Raga dan Pariwisata yang bertanggung jawab dalam mengeluarkan izin TDUP untuk usaha karaoke serta tempat usaha karaoke yang beroperasi di Kota Parepare. Penelitian ini dilakukan dengan melakukan wawancara langsung dengan narasumber pada lokasi penelitian yang kompeten dan relevan dengan topic penelitian lalu melakukan Observasi di Lapangan untuk melihat secara langsung Penyelenggaraan Usaha Karaoke. Pendekatan yang dilakukan adalah pendekatan kualitatif dengan memaparkan secara deskriptif berbagai hasil wawancara dan Observasi lalu melakukan analisis terhadap data tersebut. Hasil penelitian bahwa Pelaksanaan Peraturan Daerah Nomor 9 Tahun 2001 Tentang Penertiban Tempat Hiburan Di Kota Parepare belum efektif.
\end{abstract}

Kata Kunci: Penegakan Hukum, Hukum Perizinan, Usaha Karaoke

\begin{abstract}
This study aims to identify and understand law enforcement efforts in the implementation of Regional Regulation Number 9 of 2001 concerning Control of Entertainment Places in the City of Parepare and the factors that support and hinder the implementation of entertainment venues in the City of Parepare. Therefore, law enforcement and business supervision are needed to control the operation of a karaoke business so that it runs according to the rule. This research was conducted in the City of Parepare where the objects of research were the Licensing Board and One Door for Investment in the City of Parepare and the Office of Youth, Sports and Tourism which is responsible for issuing TDUP licenses for karaoke businesses as well as karaoke businesses operating in Parepare City. This research was conducted by carrying out direct interviews with respondents at the research location who were competent and relevant to the research topic and then conducting field observations to see firsthand the operation of karaoke businesses. The approach taken is a qualitative approach by describing the results of sharing interviews and observations descriptively and then analyzing the data. The result of this research is that the implementation of Regional Regulation No. 9/2001 on Control of Entertainment Places in the City of Parepare has not been effective.
\end{abstract}

Keywords: Law Enforcement, Licensing Law, Karaoke Business

\section{PENDAHULUAN}

Meningkatnya aktivitas ekonomi di Kota Parepare berdampak pada perubahan pola hidup maupun kebutuhan hidup masyarakat Kota Parepare. Salah satu indikatornya adalah kebutuhan masyarakat Kota Parepare akan adanya media hiburan dan wisata. Hal ini dapat dilihat dengan semakin banyaknya tempat-tempat hiburan, wisata maupun rekreasi di Kota Parepare seperti bioskop, taman bermain/park/kids stasion, bahkan tempat wisata alam. Salah satu jenis usaha hiburan yang paling kasat mata dirasakan peningkatan jumlahnya oleh warga Kota Parepare adalah rumah bernyanyi atau tempat karaoke .

Bisnis karaoke dinilai sangat potensial untuk dijalankan oleh beberapa pengusaha dikota besar di
Indonesia, tidak terkecuali di Kota Parepare. Bisnis Karaoke menjadi media hiburan yang dinikmati di Kota Pare-pare karena sebagian besar masyarakat Kota Metropolitan memiliki aktivitas kegiatan yang sangat tinggi sehingga masyarakat membutuhkan tempat rekreasi alternatif setelah menyelesaikan kegiatan hariannya. Tempat karaoke dengan fasilitas bernyanyi sebagai hiburan memberikan pilihan bagi masyarakat untuk melepas penat dari rutinitas sehari-hari.

Banyaknya usaha karaoke di Kota Parepare dengan sendirinya menjadikan karaoke sebagai salah satu penyumbang untuk pemasukan kas daerah yang signifikan. Pemerintah Kota Parepare menyadari hal ini sehingga menertibkan peraturan-peraturan daerah 
berkaitan dengan penyelenggaraan usaha karaoke secara khusus dan usaha hiburan dan pariwisata secara umum. Fungsi utama dari diterbitkannya peraturan-peraturan daerah tersebut tentu saja sebagai pengendali atas penyelenggaraan usaha, khususnya usaha karaoke. Pengendalian ini digunakan oleh pemerintah dalam rangka mengarahkan, menciptakan, membuat dalam keadaan tertentu yang di inginkan pemerintah untuk kepentingan dan kesejahteraan masyarakat.

Banyak jenis pelanggaran izin usaha yang terjadi di lapangan, beberapa pengusaha bahkan tidak memiliki Surat Izin Tanda Daftar Usaha Pariwisata dalam sosialisasi Perda No. 9 Tahun 2001. Karena masih banyak tempat karaoke lainnya di Kota Parepare yang ditengarai tidak memiliki izin usaha. Hal ini tentu saja merugikan pemerintah dan masyarakat Kota Parepare karena usaha karaoke yang tidak memiliki izin, atau yang izinya sudah kadaluarsa, tentu saja berpotensi sangat besar bahwa penyelenggaraannya tidak sesuai dengan aturan-aturan yang berlaku. Seperti kualitas layanan yang tidak terjamin, tata bangunan yang dapat membahayakan pengunjung. Bahkan dapat memiliki efek sosial yang negatif kepada masyarakat yang tinggal di sekitar tempat karaoke tersebut. Dalam usaha karaoke yang tidak memiliki izin, pemerintah Kota Parepare sebenarnya sudah melakukan beberapa langkah tindakan penertiban, namun tindakan pengawasan yang berlanjut perlu dilakukan karena hal seperti ini masih saja terus terjadi.

Selain penyelenggaraan usaha tanpa izin, banyak juga usaha karaoke yang menyelenggarakan usaha tidak sesuai dengan ketentuan yang telah ditetapkan di dalam Peraturan Daerah. Beberapa tempat usaha karaoke ada yang diduga bahkan telah didapati menjalankan usaha tidak sesuai izin atau menjalankan usaha terselubung. Wali Kota Parepare, Taufan Pawe menegaskan akan mengambil langkah tegas untuk melakukan penertiban terhadap THM (Tempat Hiburan Malam) lainnya, yang melanggar izin usaha. Taufan mengatakan, kejadian di Planet Pool menjadi pintu masuk untuk melakukan penertiban terhadap THM lainnya yang melanggar Izin usaha. Dengan langkah tersebut, diharapkan bisa menjadi awal untuk melakukan penertiban .

Penegakan Hukum yang tegas atas Peraturan Daerah oleh Pemerintah sangat diharapkan untuk mengoptimalkan manfaat dari penyelenggaraan suatu kegiatan. Penegakan hukum disini termasuk pengawasan dan pemberian sanksi. Pemerintah Kota Parepare dalam hal ini sudah menjalankan fungsinya dalam penegakan hukum tersebut yaitu pegawasan dan pemberian sanksi. Namun pelanggaran-pelanggaran perizinan usaha Karaoke masih ditemukan di banyak tempat di Kota Parepare, masih dibutuhkan penegakan hukum yang lebih tegas serta pengawasan yang berlanjut guna mengetahui sejauh mana menaati Peraturan yang berlaku.

\section{METODE}

Tipe penelitian yang digunakan penulis dalam penyusunan penelitian ini adalah penelitian hukum empiris, Penelitian hukum empiris dilakukan dengan meneliti secara langsung kelokasi Dinas Kebudayaan dan Pariwisata Kota Pare-pare, Kepala Dinas Satpol PP dan serta tempat Hiburan di kota Pare-pare dengan pertimbangan bahwa banyaknya tempat hiburan di Parepare sehingga dengan memilih lokasi ini diharapkan agar mudah untuk mengetahui kebijakan ekonomi politik dalam penertiban izin hiburan di Kota Pare-pare, maka penulis melakukan teknik, maka penulis melakukan tekni pengumpulan data dengan wawancara dan pustakaan.

\section{HASIL DAN PEMBAHASAN}

Pelaksanaan Peraturan Daerah Nomor 9 Tahun 2001 Tentang Penertiban Tempat Hiburan di Kota Parepare

Pelaksanaan Peraturan Daerah Nomor 9 Tahun 2001 Tentang Penertiban Tempat Hiburan Di Kota Parepare telah dilaksanakan sesuai dengan aturan yang berlaku.Satuan Polisi Pamong Praja Kota Parepare intens melaksanakan pemantauan dan pengawasan tempat hiburan khususnya karaoke.

Berdasarkan hasil wawancara Penulis dengan Muhammad Anzar Selaku Kasatpol PP (tanggal 21 Nopember 2020), menyatakan; Pelaksanaan Peraturan Daerah tentang Penertiban Tempat Hiburan telah sesuai dengan peraturan yang berlaku dan tetap diperketat.Sebelum pandemik Tempat Hiburan beroperasi jam 8 malam sampai jam 12 malam. Terkecuali pada malam minggu diberikan toleransi sampai jam 01.00 dini hari tapi semenjak pandemik yaitu mulai 13 maret sampai saat ini tidak dibuka, karena untuk menghindari klaster baru dari tempat hiburan karena yakin dan percaya apabila hiburan buka pasti banyak pengunjungnya.

Pemerintah Kota Parepare memang dihadapkan pada banyak tantangan dalam hal penyelenggaraan Usaha Karaoke. Meskipun Peraturan Daerah telah dibuat sedemikian rupa agar usaha karaoke yang beroperasi di Kota Parepare berjalan dengan baik masih saja banyak masalah yang dihadapi terkait penyelenggaraan usaha Karaoke seperti pelanggaran-pelanggaraan usaha yang terjadi pada beberapa usaha karaoke dikota Parepare.

Peraturan Daerah Kota Parepare Nomor 9 Tahun 2001 Tentang Penertiban Tempat Hiburan telah mengatur secara rinci mengenai ketentuan-ketentuan khusus dalam penyelenggaraan tempat hiburan, khususnya usaha karaoke. Seperti yang terdapat di dalam Pasal 3 dinyatakan bahwa;

1. Setiap tempat hiburan dan sarana usaha dilarang melakukan perbuatan dan atau memfasilitasi terjadinya kegiatan-kegiatan yang dapat mengganggu ketertiban umum;

2. Gangguan terhadap ketertiban umum dimaksud pada ayat (1) meliputi perbuatan melakukan, memberi peluang atau menyediakan fasilitas terhadap terjadinya:

a. Kegiatan asusila;

b. Kegiatan perjudian; 
c. Kegiatan penyalahgunaan narkotik, obat berbahaya dan minuman beralkohol.

Selain itu, di dalam Pasal 4 dinyatakan bahwa:

Selain ketentuan dimaksud pada Pasal 3, khusus bagi tempat hiburan diwajibkan untuk mematuhi ketentuanketentuan sebagai berikut:

a. Menghentikan sementara kegiatan selama Bulan Ramadhan, yaitu 3 (tiga) hari sebelum Pelaksanaan ibadah puasa sampai dengan 3 (tiga) hari setelah berakhirnya pelaksanaan ibadah puasa;

b. Melaksanakan seluruh ketentuan dan persyaratan teknis yang diwajibkan bagi pengoperasian tempat hiburan yaitu:

1) Menggunakan ruangan yang cukup terang, tidak boleh remang-remang;

2) Menggunakan penghalang/penyekat ruang yang harus tembus pandang;

3) Jam buka dan jam tutup sesuai yang telah ditetapkan, yaitu:

4) Jadwal aturan dalam Perda untuk pengusaha tempat hiburan adalah :

a) Minggu malam sampai dengan Jum'at malam dibuka Pukul 20.00 Wita dan ditutup Pukul 24.00 Wita;

b) Sabtu Malam dibuka Pukul 20.00 Wita dan ditutup Pukul 01.00 Wita.

5) Menggunakan tenaga pelayanan atau pramusaji yang berpakaian sopan dan tidak melanggar etika;

6) Memiliki izin tempat penjualan minuman beralkohol serta izin lainnya sesuai dengan Peraturan Daerah yang berlaku;

7) Tidak menjual barang yang tergolong barang berbahaya atau barang terlarang;

8) Tidak memberi izin memasuki tempat hiburan bagi anak

9) dibawah umur dan anak sekolah, termasuk aparat yang berpakaian dinas;

10)Bagi tempat hiburan yang menyajikan music, menggunakan volume/suara music yang tidak mengganggu ketentraman warga di sekitarnya.

Dari hasil penelitian yang dilakukan Penulis, dari jumlah keseluruhan penyelenggaraan usaha karaoke di Kota Parepare baik itu untuk jenis Karaoke Keluarga maupun Live Karaoke, masih banyak terjadi pelanggaranpelanggaran usaha seperti yang dapat dilihat pada table dibawah ini:

Tabel 1. Daftar Pelanggaran Usaha Karaoke Tahun 20172019

\begin{tabular}{lllll}
\hline Tahun & $\begin{array}{c}\text { Jumlah } \\
\text { Pelanggaran }\end{array}$ & Selesai & $\begin{array}{c}\text { Tidak } \\
\text { Selesai }\end{array}$ & $\begin{array}{c}\text { Persentase } \\
\text { Selesai dan } \\
\text { tidak Selesai }\end{array}$ \\
\hline 2017 & 8 & 7 & 1 & $87,5 \%: 12,5 \%$ \\
2018 & 4 & 4 & - & $100 \%$ \\
2019 & 2 & 2 & - & $100 \%$ \\
\hline Total & 14 & 13 & 1 & \\
\hline
\end{tabular}

Berdasarkan tabel 1 di atas, jumlah total Pelanggaran Usaha karaoke yang terjadi pada tahun 2017 adalah sebanyak 8 pelanggaran, $8(100 \%)$ dapat diselesaikan, dan pada tahun 2018 tercatat ada 4(100\%) temuan pelanggaran usaha karaoke dan 4(100\%) yang selesai, sedangkan pada tahun 2019 tercatat ada 2 temuan pelanggaran,2 (100\%) semuanya dapat terselesaikan. Dapat diketahui bahwa jumlah pelanggaran tempat Usaha Karaoke di wilayah Kota Parepare,pada tahun 2017-2019 sebanyak 14 temuan dan sebanyak 14 yang dapat diselesaikan oleh pihak Satuan Polisi Pamong Praja.

Tabel 2. Jumlah Temuan jenis-Jenis Pelanggaran Usaha Karaoke Tahun 2017-2019

\begin{tabular}{clccc}
\hline \multirow{2}{*}{ No. } & Jenis Pelanggarn Usaha & 2014 & 2018 & 2019 \\
& Karaoke & & & \\
\hline 1 & Jam Operasional & 3 & 2 & 1 \\
2 & Izin Usaha Karaoke & 2 & 1 & - \\
3 & Menjual Minuman Keras & 3 & 1 & 1 \\
\hline & Total & 8 & 4 & 2 \\
\hline
\end{tabular}

Berdasarkan table 2 di atas, maka dapat dilihat jenisjenis pelanggaran Usaha Karaoke di Kota Parepare mulai dari tahun 2017 sampai dengan tahun 2019 ada 14 jenis pelanggaran,Tahun 2017 terdapat 8 jenis pelanggaran yang dilakukan oleh pelaku usaha karaoke diantaranya pelanggaran jam operasional sebanyak 3 kasus, izin usaha karaoke sebanyak 2 kasus, dan menjual minuman keras sebanyak 3 kasus.Tahun 2018 terdapat 4 pelanggaran yang dilakukan oleh pelaku usaha karaoke diantaranya pelanggaran jam operasional sebanyak 2 kasus, izin usaha karaoke sebanyak 1 kasus dan menjual minuman keras sebanyak 1 kasus.Tahun 2019 terdapat 2 jenis pelanggaran yang dilakukan oleh pelaku usaha karaoke diantaranya yaitu pelanggaran jam operasional sebanyak 1 kasus, dan menjual minuman keras sebanyak 1 kasus.

Berdasarkan table dan uraian diatas dapat diketahui bahwa pelanggaran usaha karaoke dapat ditekan dengan dilaksanakannya sanksi kepada pelaku usaha karaoke, dengan demikian maka diharapkan jumlah pelanggaran bisa ditekan dan menurun dari tahun ke tahun.

Sejauh ini dilakukan penekanan atas pelanggaran tempat usaha karaoke yang dilakukan oleh pemilik usaha,hal ini dapat dilihat dari penurunan jumlah pelanggaran yang ditemukan pihak Satpol PP setiap tahunnya.Hal ini terjadi sebagai bentuk usaha tim kami untuk menekan pelanggaran usaha karaoke.Salah satunya dengan melaksanakan penyuluhan terkait Peraturan Daerah tentang Penertiban Usaha Karaoke kepada pemilik usaha untuk mengedukasi agar tidak terjadi lagi pelanggaran.

Berdasarkan hasil penelitian yang penulis lakukan dapat diketahui bahwa beberapa pelanggaran Usaha karaoke yang sering ditemui beberapa tahun terakhir Antara lain: 
1. Ditemukan minuman beralkohol tanpa izin pada tempat usaha karaoke;

2. Tempat usaha karaoke yang jam operasional melebih batas;

3. Tempat usaha karaoke tidak memperpanjang izin TDUP

Berdasarkan hasil penelitian yang dilaksanakan oleh penulis dapat diketahui bahwa penanganan pelanggaran yang dilaksanakan oleh Satpol PP adalah pelaksanaan penertiban yang dilakukan dengan cara:

1. Operasi penertiban di lapangan ;

2. Pengawasan perizinan usaha;

3. Pemberhentian atau pembekuan kegiatan;

4. Tindakan penegakan hukum.

Adapun sanksi yang selama ini diterapkan bagi pemilik usaha tempat karaoke apabila melanggar peraturan yang terdapat pada Peraturan Daerah Nomor 9 Tahun 2001 adalah;

1. Pembekuan atau penghentian sementara kegiatan usaha;

2. Pencabutan izin usaha;

3. Penutupan usaha.

Faktor-faktor pendukung dan penghambat pelaksanaan Penertiban Tempat Hiburan Di Kota Parepare

Penyelenggaraan Usaha Karaoke di Kota Parepare adalah Peraturan Daerah Nomor 8 Tahun 2012 Tentang Pengelolaan Kepariwisataan, peraturan ini secara jelas mengatur tentang penyelenggaraan usaha pariwisata mulai dari hak dan wewenang pihak penyelenggaraan dalam hal ini Pemerintah Kota Parepare, penyelenggaraan Usaha sampai dengan masyarakat sebagai konsumen usaha pariwisata. Dari hal dapat dilihat bahwa seluruh pihak yang merupakan stakeholder dalam usaha pariwisata bertanggung jawab dalam terwujudnya pelaksanaan peraturan di kota Parepare, banyak faktor yang mempengaruhi penegakan hukum perizinan usaha karaoke di Kota Parepare, yaitu (1) Struktur Penegakan Hukum (Pemerintah Kota Parepare); (2) Kultur dalam masyarakat, dalam hal ini penyelenggaraan usaha karaoke dan masyarakat Kota Parepare; (3) Substansi Peraturan Perundang-undangan (Peraturan Daerah Kota Parepare Nomor 8 Tahun 2012 Tentang Pengelolaan Kepariwisataan).

1. Faktor pendukung dalam Pelaksanaan Tempat Hiburan di Kota Parepare

Pada wilayah tempat Penulis melakukan penelitian yaitu Kantor Satuan Polisi Pamong Praja, Selama semua proses lancer-lancar saja factor pendukugnya yaitu persyaratan untuk membuat izin tempat hiburan tersebut sudah lengkap semua bisa langsung terproses akan tetapi jika ada yang belum lengkap persyaratannya disarankan untuk mengurus dulu misalnya : IMB atau SITU

Faktor yang medukung karena adanya Penegakan Hukum itu sendiri, dalam hal ini Pemerintahan Kota Parepare dalam menjalankan Peraturan Daerah Nomor 8 Tahun 2012 Tentang Pengelolaan Kepariwisataan. Pemerintah Kota Parepare sebagai regulator yang mengatur penyelenggaraan perda memiliki tanggung jawab yang paling besar. Seperti yang diamantkan di dalam Pasal 27 yang menyatakan Pemerintah kota dalam penyelenggaraan kepariwisataan berwewenang:

a. Pemerintah Daerah berkewenangan:

1) Menyusun dan menetapkan Rencana Induk Pembangunan Kepariwisataan Daerah;

2) Mengkoordinasikan penyelenggaraan Kepariwisataan di daerah;

3) Melaksanakan pendaftaran, pencatatan dan pendataan pendaftaran usaha pariwisata;

4) Menetapkan destinasi Pariwisata Daerah;

5) Menetapkan daya Tarik wisata daerah;

6) Memfasilitasi promosi destinasi pariwisata dan produk pariwisata yang berada wilayahnya;

7) Memeilihara asset Daerah yang menjadi daya Tarik wisata Daerah;

8) Mengalokasikan anggaran penyelenggaraan kepariwisataan;

9) Melakukan pengawasan terhadap standarisasi usaha untuk meningkatkan pelayanan pada usaha pariwisata di daerah;

10)Memberizin untuk melakukan penelitian tentang kepariwisataan kepada orang, kelompok orang dan atau lembaga institusi;

11) Mewajibkan menyerahkan sebagaian atau keseluruhan hasil penelitian kepada institusi yang memberizin untuk digunakan sebagai bahan promosi.

b. Ketentuan mengenai ketetapan rencana untuk pembangunan kepariwisataan daerah sebagaimana dimaksud pada ayat (1) huruf a diatur dengan peraturan daerah;

c. 3) Kewenangan mengkoordinasikan sebagaimana dimaksud pada ayat (1) huruf b dilakukan melalui :

1) Rapat koordinasi dengan instansi terkait dalam lingkup pemerintah kota;

2) Memfasilitasi penegakan hak atas kekayaan intelektual berkenan dengan daya Tarik wisata sesuai ketentuan peraturan Perundang-undangan.

Ada tiga hal yang menjadi perhatian penulis sehubungan dengan Faktor yang mendukung dengan adanya penegakan hukum usaha Karaoke jika melihat dari beberapa point diatas yaitu poin $\mathrm{b}$, c dan i. disebutkan bahwa pemerintahan Kota Parepare memiliki wewenang untuk Mengkoordinasikan penyelenggaraan Kepariwisataan di daerah dan melakukan pendaftaran, pencatatan dan pendataan pendaftaran usaha pariwisata dan Melakukan pengawasan terhadap standarisasi usaha untuk meningkatkan pelayanan pada usaha pariwisata di daerah.

Berdasarkan hal tersebut, pemerintah Kota Parepare memegang peranan utama dalam mewujudkan penyelenggaraan usaha karaoke yang sesuai dengan tujuan Perda tersebut. Dengan melakukan pengaturan penyelenggaraan dan pengelolaan usaha pariwisataa dalam hal ini usaha karaoke yang sesuai ketentuan untuk maka pemerintah dapat mewujudkan iklim usaha yang 
kondusif untuk perkembangan usaha dan masyarakat Kota Parepare secara keseluruhan.

Pemerintah Kota Parepare sudah menjalankan fungsinya yaitu dengan menjalankan prosedur penyelenggaraan dan Penerbitan Izin yang dilakukan melalui Dinas Pariwisata dan Badan Perizinan dan Penanaman Modal Kota Parepare. Semua pihak yang ingin menjalankan Usaha Karaoke harus mendaftarkan usahanya di Dinas Pariwisata melalui Badan Perizinan Terpadu dan Penanaman Modal Kota Parepare.

Selain melakukan pencatatan, pendataan dan penerbitan TDUP, tugas lain dari Pemerintah Kota Parepare yang diamanatkan oleh Perda adalah mengontrol dan mengawasi penyelenggaraan usaha karaoke tersebut agar sesuai dengan ketentuan, maka dari itu untuk menjalankan tugas tersebut pemerintah Kota Parepare membentuk Tim Pembinaan dan Pengawasan Usaha Pariwisata yang secara khusus melakukan pengawasan terhadap segala jenis usaha pariwisata yang beroperasi di Kota Parepare termasuk usaha karaoke yang dibuat dalam Undang-Undang Nomor 9 Tahun 2001 Tentang Penertiban Tempat Hiburan.

Berdasarkan hasil penelitian penulis, ditemukan beberapa factor yang menjadi pendukung Pelaksanaan Peraturan Daerah tentang Tempat Hiburan antara lain :

a. Faktor anggaran

b. Sarana dan Prasarana

Untuk mendapatkan gambaran lebih jelas mengenai kedua faktor tersebut di atas, dijelaskan dalam uraian secara detail seperti berikut ini:

\section{a. Faktor Anggaran}

Anggaran yang dimaksud yaitu berupa ketersediaan dana operasional yang dimiliki oleh Satpol PP digunakan dalam mendukung pelaksanaan tugas. Anggaran merupakan salahsatu faktor utama dalam mendukung keberhasilan sebuah organisasi.Berhasil tidaknya sebuah organisasi sangat tergantung dari ketersediaan anggaran yang dapat digunakan secara efisien untuk membiayai kegiatan organisasi.

Anggaran merupakan dana operasional yang dimiliki Satpol PP digunakan untuk mendukung pelaksanaan tugas.Anggaran merupakan ujung tombak organisasi dalam menjalankan organisasi tanpa ada pengelolaan anggaran, perencanaan dan penganggaran, pelaksanaan anggaran, pembiayaan dan sebagainya keuangan yang ada di suatu organisasitidak akan digunakan dengan baik.

Anggaran merupakan salah satu faktor pendukung penting dalam suatu organisasi.Untuk itu pengelolaan anggaran harus dikelola dengan baik agar supaya roda pemerintahan akan berjalan dengan baik seperti yang diatur dalam Peraturan Pemerintah No.13 Tahun 2006 Tentang Pedoman Pengelolaan Anggaran Daerah.Pengelolaan anggaran daerah adalah keseluruhan kegiatan yang meliputi perencanaan, pelaksanaan, penatausahaan, pelaporan, pertanggungjawaban dan pengawasan anggaran daerah.

\section{b. Sarana dan prasarana}

Sarana dan Prasarana merupakan fasilitas yang tersedia yang digunakan dalam menunjang setiap pelaksanaan dalam tugas dan fungsi aparat seperti gedung, kendaraan oprasional, meja, kursi, computer dan fasilitas lainnya yang mendukung. Karena saran dan prasarana untuk lebih efektif aktivitas merupakan factor penunjang dan pendukung dalam melakukan aktivitas kegiatan organisasi.

Ketersediaan sarana dan prasarana di Kantor Satpol PP Kota Parepare dalam setiap menentukan keberhasilan pelaksanaan tugas organisasi. Dimana Satpol PP Kota Parepare dalam setiap melaukan kegiatan maka Peranan saran dan prasarana menjadi sangat penting karena sebagai pendukung dan perlengkapan yang digunakan untuk melaksanakan tugas dalam organisasi. Dengan adanya sarana dan prasarana yang baik agar lebih untuk lebih baik diharapkan dapat menciptakan kondisi yang menyenangkan baik bagi pimpinan dan aparatnya juga masyarakat yang menerima layanan.

Karena adanya Sarana dan Prasarana Operasional dinilai membuat kinerja Dinas Satuan Pamong Praja (Satpol PP) Parepare menjadi maksimal.

2. Faktor Penghambat Pelaksanaan Penertiban Tempat Hiburan Di Kota Parepare.

Pada wilayah tempat penulis melakukan penelitian yaitu Kantor Satuan Polisi Pamong Praja ditemukan berbagai macam factor yang menghambat pelaksanaan Peraturan Daerah No.9 Tahun 2001 Tentang Penertiban Tempat Hiburan.Untuk mengetahui lebih jelas harus dicari factor-faktor penyebabnya yang langsung berkaitan dengan kondisi dan situasi dengan masyarakat.

Disamping factor-faktor tersebut,dari hasil penelitian penulis,juga akan mengemukakan beberapa factor yang menghambat Pelaksanaan Peraturan Daerah tentang Tempat Hiburan antara lain :

a. Faktor Kesadaran Masyarakat

Satpol PP Kota parepare giat melaksanakan penyuluhan dan patroli terkait dengan Peraturan Daerah Tentang Penertiban Tempat Hiburan Malam.Setidaknya di masa pandemic ini setiap malam dilaksanakan pemantauan tempat-tempat hiburan malam. Penegakan Hukum terhadap Peraturan Walikota Kota Parepare Nomor 31 Tahun 2020 yang mengatur protocol kesehatan di kota Parepare.Faktor yang mempengaruhi kesadaran masyarakat adalah ketaatan masyarakat atas Peraturan Daerah tersebut.Dengan demikian seluruh kepentingan masyarakat akan bergantung pada ketentuan dalam Peraturan Daerah itu sendiri.Namun juga ada anggapan bahwa kepatuhan masyarakat justru disebabkan dengan adanya takut terhadap hukuman maupun sanksi yang akan didapatkan.

Berdasarkan hasil penelitian yang dilaksanakan oleh penulis,diketahui bahwa lingkungan yang padat masyarakatnya namun tidak tanggap dan acuh mengenai peraturan daerah yang ada akan berakibat buruk bagi warganya,ada beberapa warga masyarakat dalam memberikan informasi ataupun komunikasi antara 
warganya yang dilakukan justru mengarah kearah yang salah karena banyaknya masyarakat khususnya pemilik usaha yang apatis dan acuh tak acuh terhadap peraturan daerah tersebut sehingga memicu terjadinya pelanggaran tempat usaha karaoke yang berulang-ulang.

Faktor lingkungan ini menurut Muhammad Anzar selaku Kasatpol PP Kota Parepare (wawancara tanggal 21 Nopember 2020) bahwa ;Faktor kesadaran masyarakat ini merupakan factor banyaknya pemilik usaha karaoke yang bersikap acuh tak acuh dengan peraturan daerah tentang tempat usaha karaoke, hal inilah yang memicu pelanggaran secara berulang-ulang. Oleh karena itu tugas dari satpol pp untuk semakin tegas dan konsisten dalam menjatuhkan sanksi kepada pelanggar tersebut.

b. Faktor perizinan

Proses perizinan usaha karaoke sebenarnya dapat digunakan pemerintah untuk mengendalikan dan mengontrol kegiatan masyarakat.Hal itu seperti misalnya Nampak dalam hal anggota masyarakat sebagai pemegang izin diwajibkan untuk mendaftar ulangataupun mengajukan perpanjangan izinnya untuk setiap periode tertentu.Dalam hal seperti itu setiap kali perndaftaran ulang atau perpanjangan dilakukan, maka akan dilihat pula dampak dari kegiatan yang diizinkan.Apabila kegiatan itu memberikan dampak positif bagi masyarakat di sekitarnya maupun bagi pemerintah sendiri,atau setidak-tidaknya tidak menimbulkan kerugian dan dampak negative bagi pihak lain,maka perpanjangan atau pendaftaran dapat dilayani. Namun jika yang terjadi adalah hal sebaliknya,atau bahkan tidak sesuai dengan peraturan perundang- undangan maka perpanjangan izin tersebut dapat dikaji terlebih dahulu.

Berdasarkan hasil penelitian yang dilakukan oleh penulis ditemukan bahwa alasan pemilik usaha tidak memperpanjang izin usaha karaoke. karena Faktor Perizinan ini menurut $\mathrm{Hj}$. Darmawati selaku Kasi Pembinaan dan Standarisasi Usaha Pariwisata di Dinas Kepemudaan, Olahraga dan Pariwisata Kota Parepare ( wawancara tanggal 20 Nopember 2020 ) bahwa : Proses kajian teknis dan Pemberi Rekomendasi Penerbitan Izin biasanya hanya 1 hari paling lama 3 hari

c. Faktor kualitas sumber daya manusia

Untuk memperoleh hasil yang optimal mengenai Penegakan Peraturan Daerah tentang Penertiban Hiburan Malam maka diperlukan sumber daya aparatur yang memadai.Secara umum sumber daya aparatur satuan polisi pamong praja dapat menjalankan tugasnya dengan baik khususnya dalam hal melakukan penertiban dan pengawasan tempat hiburan karaoke.Sumber daya manusia merupakan factor yang sangat penting dalam menentukan keberhasilan suatu organisasi.Peningkatan sumber daya manusia akan mempengaruhi kinerja dari pegawai Satpol PP.

Berdasarkan hasil penelitian ditemukan bahwa faktor kualitas sumber daya manusia merupakan factor penghambat dalam pelaksanaan kegiatan Peraturan Daerah karena kurang jumlah personil Satuan Polisi Pamob Praja Di Kota Parepare: a. Belum berimbangnya jumlah aparat Satpol PP terhadap jumlah penduduk;

b. Kurangnya tenaga ahli;

Rendahnya sumber daya manusia pada Kantor Satuan Polisi Pamong Praja Kota Parepare di karenakan kurangnya lembaga yang bekerja sama dengan Pemerintah yang memadai.

3. Tanggapan Responden Tentang Faktor Pendukung Dalam Pelaksanaan Peraturan Daerah Nomor 9 Tahun 2001 Tentang Penertiban Tempat Hiburan di Kota Parepare.

Penelitian yang dilakukan penulis dilaksanakan dengan membagikan beberapa angket kepada masyarakat di sekitar lokasi Tempat Hiburan Malam di Kota Parepare.Dengan Membagikan angket kepada 50 orang di Tempat Hiburan Malam Kota Parepare secara rinci dapat dilihat pada table dibawah ini :

Table 3. Pendapat Responden terhadap Faktor Pendukung

Dalam Pelaksanaan Peraturan Daerah Nomor 9 Tahun

\begin{tabular}{lcc}
\multicolumn{3}{c}{2001} \\
\multicolumn{1}{c}{ Jawaban } & Tanggapan & Presentase \\
\hline Faktor Anggaran & 41 & $82 \%$ \\
Faktor Sarana dan Prasarana & 9 & $18 \%$ \\
\hline Jumlah & 50 & $100 \%$ \\
\hline
\end{tabular}

Berdasarkan uraian data diatas dapat diketahui bahwa jumlah responden yang berpendapat bahwa faktor pendukung dalam pelaksanaan peraturan Daerah Tentang tempat Hiburan Sebanyak 50 responden, kemudian yang berpendapat bahwa faktor Anggaran adalah sebagai bagian dari faktor pendukung sebanyak $41(82 \%)$ dan jumlah responden yang berpendapat terhadap faktor Sarana dan Prasarana sebanyak 9 (18\%) adapun jumlah tatal keseluruhan tanggapan Responden sebanyak 50 dan Presentase $100 \%$.

4. Tanggapan Responden Tentang Faktor Penghambat Dalam Pelaksanaan Peraturan Daerah Nomor 9 Tahun 2001 Tentang Penertiban Tempat Hiburan di Kota Parepare.

Penelitian yang dilakukan penulis dilaksanakan dengan membagikan beberapa angket kepada masyarakat di sekitar lokasi Tempat Hiburan Malam di Kota Parepare.Dengan Membagikan angket kepada 50 orang di Tempat Hiburan Malam Kota Parepare secara rinci dapat dilihat pada table dibawah ini :

Table 4. Pendapat Responden terhadap Faktor

Penghambat Dalam Pelaksanaan Peraturan Daerah Nomor 9 Tahun 2001

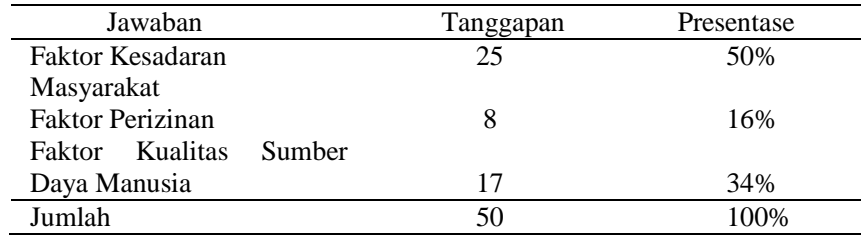

Berdasarkan uraian data diatas dapat diketahui bahwa jumlah responden yang berpendapat bahwa faktor penghambat dalam pelaksanaan Peraturan Daerah Tentang Tempat Hiburan Sebanyak 25 (50\%) responden, 
kemudian yang berpendapat bahwa faktor perizinan adalah faktor penghambat sebanyak $8(16 \%)$ dan jumlah responden yang berpendapat sedangkan faktor Sumber Daya Manusia dari Satpol PP adalah faktor penghambat sebanyak 17 (34\%) adapun jumlah total keseluruhan Tanggapan responden sebanyak 50 dan presentase $100 \%$.

Upaya Satuan Polisi Pamong Praja Untuk menanggulangi Pelanggaran yang dilakukan oleh pemilik usaha Tempat Hiburan di Kota Parepare, Terkait dengan tugas pokok Satuan Polisi Pamong Praja untuk memelihara dan menyelenggarakan ketertiban dan ketertiban umum, perlindungan masyarakat, menegakkan Peraturan Daerah, Peraturan Walikota dan Keputusan Walikota,maka permasalahan tempat hiburan karaoke yang merupakan salah satu Peraturan Daerah adalah salah satu tanggung jawab penting yang diemban oleh pihak Satpol PP.Diperlukan suatu tindakan yang tepat untuk dapat mengatasi permasalahan yang sedari dulu melekat dalam kehidupan sehari-hari di masyarakat. Dalam melaksanakan upaya penanggulangan pelanggaran yang dilakukan oleh pemilih usaha karaoke pihak Satpol PP dalam hal ini khususnya Satuan Polisi Pamong Praja Kota Parepare menempuh dengan tiga cara yaitu secara preemtif, preventif dan represif.

a. Upaya Pre-Emtif

Merupakan upaya awal yang dilakukan oleh pihak Satpol PP untuk mencegah terjadinya pelanggaran.Usaha-usaha yang dilakukan dalam penanggulangan secara Pre-Emtif adalah menanamkan nilai-nilai/norma-norma yang baik kepada masyarakat.Dalam penanggulangan pelanggaran Perda secara pre-emtif pihak Satpol PP Kota Parepare telah mengadakan penyuluhan peraturan daerah kepada masyarakat.Penyuluhan perda tesebut bekerja sama dengan bagian hukum Pemerintah Kota Parepare dan instansi terkait. Kegiatan penyuluhan ini merupakan upaya untuk melakukan pencegahan dan menekan jumlah pelanggaran Perda yang berpotensi dilakukan oleh masyarakat khususnya pemilik usaha karaoke di Kota Parepare.

Penyuluhan perda adalah kegiatan untuk meningkatkan kesadaran masyarakat berupa penyampaian dan penjelasan peraturan perda kepada masyarakat dalam suasana informal sehingga tercipta sikap dan perilaku masyarakat yang berkesadaran atas peraturan perda yang berlaku. Disamping mengetahui, memahami, menghayati peraturan perda, masyarakat dalam hal ini pemilik usaha karaoke diharapkan dapat mematuhi dan menaati peraturan perda tentang tempat hiburan.Eksistensi penyuluhan sangat diperlukan karena saat ini, meski sudah banyak anggota masyarakat yang sudah mengetahui dan memahami apa yang menjadi hak dan kewajibannya menurut hukum, namun masih ada yang belum dapat bersikap dan berperilaku sesuai dengan peraturan daerah yang berlaku.

Konsep penyuluhan peraturan daerah saat sekarang ini harus lebih diarahkan pada pemberdayaan masyarakat. Masyarakat, yang menjadi sasaran penyuluhan peraturan daerah, diharapkan tidak saja mengerti akan kewajibankewajibannya dalam kehidupan berbangsa dan bernegara tetapi juga diharapkan mengerti hak-hak yang dimilikinya. Kesadaran akan hak-hak yang dimilikinya.Kesadaran akan hak-hak yang dimilikinya ini akan memberikan perlindungan terhadap kepentingankepentingan mereka.

Masyarakat dibuat sadar bahwa mereka mempunyai hak tertentu yang apabila dilaksanakan akan membantu mensejahterakan hidupnya.Karena itu mereka perlu mendapat penyuluhan terkait peraturan daerah agar tahu bahwa peraturan daerah tersebut menjanjikan perlindungan bagi masyarakat khususnya pelaku usaha karaoke di kota parepare. Kegiatan penyuluhan dilaksanakan di Kantor Satuan Polisi Pamong Praja dengan mengundang para pelaku usaha maupun pemilik usaha karaoke.

Dalam upaya penanggulangan pelanggaran perda tempat usaha karaoke,upaya pre-emtif ( pencegahan ) dirasa mempunyai peran yang sangat penting dan sangat bermanfaat.

Menurut Muhammad Anzar selaku Kasatpol PP Kota Parepare (wawancara tanggal 16 Nopember 2020) menjelaskan bahwa; Kegiatan penyuluhan intens dilakukan untuk menekan dan mencegah jumlah pelanggaran perda yang berpotensi dilakukan masyarakat.

b. Upaya Preventif

Upaya ini merupakan tindak lanjut dari upaya PreEmtif yang masih dalam tataran pencegahan sebelum terjadinya kejahatan. Dalam upaya preventif yang ditekankan adalah menghilangkan kesempatan untuk dilakukannya kejahatan. Upaya ini berupa patrol dan pengawasan secara rutin dan berkelanjutan. Kegiatan ini dilakukan oleh pihak Satuan Polisi Pamong Praja Kota Parepare di tempat usaha karaoke di wilayah Kota Parepare.

Menurut analisis penulis upaya preventif ini adalah upaya yang masih dalam tataran pencegahan sebelum terjadinya perbuatan. Dalam upaya preventif ditekankan adalah menghilangkan kesempatan untuk melakukan tindak pidana, berikut ini merupakan upaya-upaya preventif dalam penanggulangan pelanggaran tempat usaha karaoke yaitu:

1) Melakukan operasi dan pengawasan di tempattempat usaha karaoke, Untuk mencegah terjadinya pelanggaran yang dilakukan oleh pemilik usaha karaoke di wilayah Kota Parepare

2) Mengadakan Patroli dan Pengawasan secara Rutin dan Berkelanjutan, Patroli dan pengawasan secara rutin dan berkelanjutan yang dilakukan oleh Satuan Polisi Pamong Praja Kota Parepare yaitu khususnya di tempat-tempat usaha karaoke di wilayah Kota Parepare.

3) Melakukan penyelidikan dan pengintaian, Satuan Pamong Praja didukung oleh Tim Intelijen yang intens mengumpulkan informasi dan deteksi dini akan pelanggaran perda khususnya tempat usaha karaoke di Kota Parepare. 
5. Upaya refresif;

Untuk mengatasi masalah pelanggaran tempat usaha Hiburan, selain tindakan Preventif dan Pre-Emtif, dapat pula diadakan tindakan reprersif, Antara lain dengan pemberian sanksi kepada pelanggar.

\section{KESIMPULAN DAN SARAN}

Berdasarkan uraian pembahasan dan hasil di atas, maka dapat ditarik kesimpulan sesuai dengan pokok perasalahan ialah Pelaksanaan Peraturan Daerah Nomor 9 Tahun 2001 Tentang Penertiban Tempat Hiburan Pengawasan terhadap penyelenggaraan usaha karaoke dilakuakan oleh Tim Pembinaan dan Pengawasan Satuan Polisi Pamong Praja Kota Parepare. Pelaksanaan Pencegahan dilakukan melalui kegiatan- kegiatan dalam bentuk penyuluhan dan tindakan preventif oleh pihak Satuan Polisi Pamong Praja Kota Parepare.Sedangkan tindakan penertiban dilakukan dengan cara operasi penertiban di lapangan, pengawasan perizinan usaha, pemberhentian atau pembekuan kegiatan dan tindakan penegakan hukum. Faktor pendukung dalam Pelaksanaan Penertiban Tempat Hiburan adalah adanya anggaran dan ketersediaan dana operasional, dan sarana prasarana. Kemudian factor penghambat adalah karena kurangnya kesadaran masyarakat dan pemilik usaha karaoke, kemudian factor perizinan dan factor sumber daya manusia.

\section{DAFTAR PUSTAKA}

Ade Saptono. 2010. Hukum dan Kearifan Lokal. Grasindo, Jakarta.

M.rasyid. 2000. Otonomi Daerah Negara Kesatuan. Yogyakarta, Penerbit : Pustaka Pelajar

Sidu Wasistiono. 2003. Aspek Hukum Pengawasan Melekat Dalam Lingkungan Aparatur, Rineka Cipta. Jakarta.

Suryaningrat. 1997. Evaluasi Kebijakan Publik, Balairung Suwandi. 2005. Metode Penelitian Kualitatif Pendekatan Kuantitatif,kualitatif, dan R\&D, Alfabeta. Bandung.

Soerjono. Soekanto dan Srimamudji. 2001. Penelitian Hukum Normatif, Penerbit : Indhillco, Jakarta.

Tajuddin. 2000. Teori Budaya Organisasi, Rineka Cipta, Jakarta.

Yani, I., Karnaeni, G., \& Bahri, S. (2020). Pengembangan E-Government Pada Bagian Pemerintahan Sekertariat Daerah Kabupaten Majene. Jurnal Paradigma Administrasi Negara, 2(1), 1-4. 